\title{
The impact of simplification of judicial procedures on access to judicial systems: the case of the colombian abstract judicial review
}

\author{
O impacto da simplificação dos procedimentos judiciais \\ no acesso aos sistemas judiciais: o caso do controle \\ abstrato colombiano
}

Hernán L. Correa-Cardozo ${ }^{1}$

\begin{abstract}
The objective of this paper is to analyze the impact of simplification of procedures to access the judicial system, especially regarding disadvantaged groups located in developing countries. The claim that the paper will defend is that even though simplification of procedures is, according to a traditional understanding, and adequate and efficient mechanism to improve and to facilitate the access to the judicial system, in some cases this simplification is not enough to accomplish that objective. Merely legal reform on procedures would ignore the effect of judicial decisions on the "real definition" of procedures. In order to prove this claim, I will refer to the case of Colombian judicial review by the Constitutional Court.
\end{abstract}

\section{KEYWORDS}

Access to justice; judicial review; procedural reforms; Colombian Constitutional Court.

\section{RESUMO}

O objetivo deste artigo é analisar o impacto da simplificação dos procedimentos de acesso ao sistema judicial, especialmente em relação a grupos desfavorecidos localizadas em países em desenvolvimento. A alegação defendida neste trabalho é que, embora a simplificação dos procedimentos seja, de acordo com um entendimento tradicional, um mecanismo adequado e eficaz para melhorar e facilitar o acesso ao sistema judicial, em alguns casos, esta simplificação não é suficiente para conseguir esse objetivo. Uma simples reforma legal/normativa sobre os procedimentos pode ignorar o efeito das decisões judiciais sobre uma "definição real" dos procedimentos. Para provar esta afirmação, tratarei do caso do controle de constitucionalidade realizado pelo Tribunal Constitucional colombiano.

\footnotetext{
1 JD, Universidad Nacional de Colombia. M.Sc. in Law, Universidad de los Andes (Colombia). LL.M Georgetown University Law Center (Washington D.C.). Auxiliary Magistrate at Colombian Constitutional Court, and Constitutional Law Lecturer at Universidad de los Andes.
} 


\section{PALAVRAS-CHAVE}

Acesso à justiça; controle de constitucionalidade; reformas processuais; Tribunal Constitucional Colombiano.

\section{INTRODUCTION}

"And Justice for all" means fair and equal access to the system of justice. It is not only an objective of the judicial administration in the American tradition, but also a well-established goal of the judiciary in any democratic system. ${ }^{2}$ For this reason, it is common that projects on judicial reform are focused on improving access to justice as a main factor of strengthening the Rule of Law. One of the strategies related to expansion of access is simplification of judicial procedures.

The objective of this paper is to analyze the impact of simplification of procedures to access the judicial system, especially regarding disadvantaged groups located in developing countries. ${ }^{3}$ The claim that the paper will defend is that even though simplification of procedures is, according to a traditional understanding, and adequate and efficient mechanism to improve and to facilitate the access to the judicial system, in some cases this simplification is not enough to accomplish that objective. Merely legal reform on procedures would ignore the effect of judicial decisions on the "real definition" of procedures. In order to prove this claim, I will refer to the case of Colombian judicial review by the Constitutional Court. In this scenario, although the

Colombian Constitution and the statutory law provide simple requirements to the "Action of Unconstitutionality," the Court has levied, through its decisions (named precedent-based requirements), a higher standard of admissibility.

Accordingly, as a conclusion, the paper will offer some possible solutions about the improvement of the access to justice taking into account these precedent-based requirements. I will explain that although these requirements are necessary in order to protect the separation of powers and the democratic principle, a proper access to justice requires also (1) a statutory enactment of the requirements of admissibility of claims, through a detailed regulation that can be known by all citizens, not only by lawyers and legal counselors familiar with the "informal and unwritten procedures" of the Court, (2) actions regarding the promotion of legal literacy of the judicial review proceedings as a part of the political rights of the Colombian citizens, particularly those who belong to disadvantaged populations and (3) adequate mechanisms of measuring and accountability of the Court's decisions regarding admissibility. These mechanisms would prevent precedent-based requirements from imposing a disproportionate burden on access to justice, particularly against disadvantaged groups and minorities.

\footnotetext{
2 See Tom Bingham, The Rule Of LaW (Penguin Global, 2011), at 55.

3 For the purpose of this paper, the concept of "disadvantaged groups" or "disadvantaged populations" has a broad sense. It is includes different kind of minorities, such as based on economic reasons (the poor), or for political factors that cause discrimination, as women, LGTB groups, immigrants, indigenous peoples, and so forth. Although most of the studies regarding access to disadvantaged groups are focused on the poor, this paper extrapolates some categories of those analyses to other minorities. See Stephen Golub, The Legal Empowerment Alternative, in Promoting the Rule of LAW AbRoAd. In SEARCH OF KNowledge (Thomas Carothers ed., 2006).
} 
Therefore, the paper will adopt the following structure: In the first section, I will summarize the main aspects of simplification of procedures as a principal objective of judicial reform, mainly with regard to improvement of access to the judicial system. In the second part, I will explain the structure of the abstract judicial review in Colombia and how important legal reforms pointed out the simplification of procedures as an instrument to expand access of the citizens to abstract judicial review.

In the third section, I will succinctly analyze the link between the judicial review and social change in developing countries, specifically the relation between access to justice simplification of procedures and public interest litigation. In this stage, the paper will refer to the experience of Colombian Abstract Judicial Review and a brief analysis of access to justice in India and the experience of the "epistolary jurisdiction" as a broad precedent-based method of access to the judicial system to the poor.

In the fourth part, I will explain how simplification of procedures in the Colombian case has been modified by the precedent-based requirements of admissibility, derived to the argumentative conditions of the Public Action of Unconstitutionality stipulated by case law. In the same section, the paper will propose an outline on the arguments that support as well as the problems that these requests offer.

Finally, in the fifth section, the paper will conclude that although the reasons that support precedent-based conditions are closely linked to the core of the constitutional principles, the protection of the Rule of Law, in the case of the Colombian Action of Unconstitutionality, requires actions on (1) legal reform, (2) legal literacy, and (3) mechanisms of judicial measuring and accountability.

\section{SIMPLIFICATION OF PROCEDURES AS A MAIN OBJECTIVE OF JUDICIAL REFORM}

According to the traditional approach on the relation between Rule of Law and judicial reform, the improvement of judicial administration is based on the accomplishment of the following conditions or key elements: fairness and impartiality, soundness of decision, accessibility, efficiency, independence and credibility. ${ }^{4}$ A judicial decision accomplishes the requirement of fairness when based exclusively on the analysis of facts and sources of law, instead of any other subjective bias, such as political influence, ethnic, income, social status, and so forth. Soundness is related to the application of the law through high professional standards. On the other hand, accessibility means the guarantee in favor of minorities to access to the system of justices, as well as adequate legal representation. Efficiency claims for speed in the decisional process and a reasonable use of resources. A system of justice is independent when it can act in an autonomous way from other branches of government and facilitates accountability of its actions by the citizens. Finally, credibility of a system of justice is linked to perception of the citizens about the judiciary as a fair and proper venue to disputes' resolution.

Access to justice is a component of the clause of equal protection under the law, as well as the due process clause in the Colombian Constitution. In a democratic society

\footnotetext{
4 Christina Biebesheimer and J. Mark Payne, IDB Experience in Justice Reform: Lessons Learned and Elements for Policy Formulation, Technical Papers Series published by the State, Governance, and Civil Society Division, Sustainable Development Department, Inter-American Development Bank (November 2001), at 4.
} 
the State should guarantee that any citizen, regardless of her personal condition, can access an "effective" judicial relief for grievances. Indeed, access to justice is considered a fundamental right, recognized in several international statutes on human rights. ${ }^{5}$ This right must be understood in a broad sense. It is not limited to the possibility to file a claim before the courts. Access is a complex guarantee that includes several components. As Yash Ghai and Jill Cottrell explain, access to justice has a narrow, a broad, and an intermediate understanding. ${ }^{6}$ The narrow concept of access is focused on the institutions that build the judiciary, particularly courts and related bodies. The broader concept of access includes "the process of law making, the contents of the law, the legitimacy of the courts, alternative models of legal representation and dispute settlement." " Lastly, the intermediate concept of access addresses formal and informal mechanisms of dispute resolution, except by law making process or content of law.

Simplification of procedures is a strategy of improving access that combines the first two components of access to justice. The rationale that supports this strategy is simple: Complex judicial procedures cause a barrier to access to justice and also originate systematic backlogs, which affect an efficient decision-making process. Hence, an easy and not costly way to expand access to justice is legal reform about new statutes that build a new and simpler judicial procedure. For instance, simplification of procedures has been used in the United Kingdom, particularly regarding civil procedures on small claims. ${ }^{8}$ In this scenario, policymakers consider that simplification of procedures reduces courts fees and attorney fees, as well as brings more flexibility to judges in order to resolve these controversies promptly.

Thus, simplification of procedures is a strategy of judicial reform that intends to change the emphasis in judicial procedures to substantial matters and particularly dispute resolution. If the main goal of judicial systems is providing relief for claims and grievances, resources should be focused on defining the scope and outcomes of the rights

${ }^{5}$ Access to an "effective judicial remedy" is a well-known standard in International Human Rights Law. See International Covenant on Civil and Political Rights, Dec. 16, 1966, S. Treaty Doc. No. 95-20, 6 I.L.M. 368 (1967), 999 U.N.T.S. 171. art 2, section 2. "Each State Party to the present Covenant undertakes:

(a) To ensure that any person whose rights or freedoms as herein recognized are violated shall have an effective remedy, notwithstanding that the violation has been committed by persons acting in an official capacity;

(b) To ensure that any person claiming such a remedy shall have his right thereto determined by competent judicial, administrative or legislative authorities, or by any other competent authority provided for by the legal system of the State, and to develop the possibilities of judicial remedy;

(c) To ensure that the competent authorities shall enforce such remedies when granted."

See also American Convention on Human Rights, Nov. 21, 1969, 1144 U.N.T.S. 143. art 25 "Right to Judicial Protection" "1. Everyone has the right to simple and prompt recourse, or any other effective recourse, to a competent court or tribunal for protection against acts that violate his fundamental rights recognized by the constitution or laws of the state concerned or by this Convention, even though such violation may have been committed by persons acting in the course of their official duties.

2. The States Parties undertake:

a. to ensure that any person claiming such remedy shall have his rights determined by the competent authority provided for by the legal system of the state;

b. to develop the possibilities of judicial remedy; and

c. to ensure that the competent authorities shall enforce such remedies when granted."

6 Yash Ghai and Jill Cottrell, The rule of law and access to justice, in MARGINALIZED COMmUnitIES AND AcCESS tO

JUSTICE (2010), at 3.

7 Id, at 3 .

8 John Baldwin, Access to Justice: The English Experience with Small Claims, PREM NotES, (World Bank, 2000). 
involved in the case, instead of dealing with the meaning of judicial procedures. ${ }^{9}$ In other words, judicial procedures must be just a framework to the adjudication process, not a goal itself of judicial systems. For this reason, one of the common objectives in projects about judicial reform is the necessity of simplification of procedures, particularly in order to improve the social conditions of disadvantaged populations who cannot afford counseling services to cope with complex and non-transparent procedural issues. ${ }^{10}$

The arguments explained above demonstrate that there is an agreement about the relation between simplification of procedures and improvement of access to justice. Different and even competitive approaches about this topic confirm such accord. From the side of Law and Economics, Richard Posner considers that judicial reform in developing countries might be concentrated in simplification of procedures as the easiest way to improve their systems of justice and facilitate disputes settlement and foreign investment. ${ }^{11}$ On the other side, related to the link between legal empowerment of the poor and better systems of justice, Stephen Golub concludes that improvement of capacities of disadvantaged populations is connected with more flexible ways to the relationship between State (not only judiciary) and citizens. These new mechanisms may include using paralegals, education in a rights-based perspective, legal literacy and, among others strategies, simpler procedures. ${ }^{12}$

Therefore, at least from a theoretical perspective simplification of procedures is closely related to improvement of access to judicial system. Nevertheless, this paper intends to demonstrate that legal reform on simplification is not a sufficient measure in order to ensure that broad access. Moreover, other measures are needed as well. The case of the Colombian abstract judicial review provides some interesting elements about this debate.

\section{THE ABSTRACT JUDICIAL REVIEW IN COLOMBIA: A CASE OF SIMPLIFICATION OF PROCEDURES}

The Judicial Review in Colombia has a long-time tradition of wide and open access. According to the Constitutional Amendment Acto Legislativo 3 of $1910,{ }^{13}$ the

\footnotetext{
9 The subordination of substantial matters by judicial procedures in legal adjudication is typical of judicial systems in developing countries. For instance, the Lawyers Committee for Human Rights explains, regarding the conditions on Venezuelan judiciary prior to Rule or Law reforms during the 90s, that "legal norms tend to be applied in a very formal manner where the ability to literally comply with procedural requirements may be more important than the normative

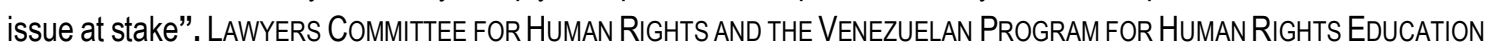
and Action, HalfWAY To Reform, (The World Bank and the Venezuelan Justice System, 1996).

$10 \mathrm{ld}$, at 111.

11 See Richard Posner, Creating a Legal Framework for Economic Development, in THE WoRLd BANK ReSEARCH OBSERVER, Vol. 13, No. 1 (February 1998), pp.1-11

12 Golub, supra note 1, at 162. "True, legal empowerment can involve lawyers pursuing sophisticated public interest litigation in some contexts (...) But legal empowerment can equally involve a group of women who become aware that they have rights without knowing the details of the law, or who learn what government office to approach for certain services and how to do so, and whose knowledge complements literacy, livelihood, or organizing efforts that enhance their power to battle domestic violence, assert inheritance rights, or otherwise pursue their priorities."

${ }^{13}$ This amendment modified the Colombian Constitution of 1886, adding the Public Action of Unconstitutionality as a part of the jurisdiction of the Colombian Supreme Court.
} 
Colombian Supreme Court had jurisdiction to "protect" the Constitution. ${ }^{14}$ One of the mechanisms to comply with this function is the Public Action of Unconstitutionality (hereinafter PAU), a judicial procedure that allows any Colombian citizen to file lawsuits in order to get a decision of the Court about the constitutional validity of laws of Congress and Executive Branch Decrees "with force of law."15

In the PAU is not necessary to bring before the Court a specific claim regarding liability of the defendant. Instead of this, the lawsuit is filed in an abstract basis and in defense of the public interest. ${ }^{16}$ In the PAU, citizens demonstrate to the Court that a national law violates a constitutional rule. Therefore, the plaintiff does not need to prove any particular interest on the case or on the facts that support the claim. In order words, the citizen expresses before the Court an abstract ${ }^{17}$ comparison between the Constitution and the "accused" law, in order to obtain a decision that invalidates the latter. This type of access to judicial review finds its roots in the German model of abstractcentralized "control of constitutionality" designed by Hans Kelsen and applied in Germany, Spain and subsequently several Latin American countries through the constitutional amendments in this region at the end of the Twentieth Century. ${ }^{18}$

Although the wide and open access to the PAU was enacted since 1910, during the rule of the Constitution of 1886 (1886-1991), the action was scarcely used by citizens. As Cepeda-Espinosa states "strong economic and other powerful pressure groups made use of it in practice, proving that the publicly available legal channel originally devised to defend the public interest had become an instrument for the promotion of cleverly disguised private interests." ${ }^{19}$ Also, another reason that would explain this limited using of PAU is the nature of the 1886 Constitution, based on a narrow role of the State in the society and a consequent limited enacting of rights in favor of individuals. This lack of connection between the interest of the citizens and the constitutional issues worked as a deterrent of a broad and common use of the PAU. ${ }^{20}$

${ }^{14}$ About the historical framework of the Public Action of Unconstitutionality See JORGE GONZÁLEZ JÁCOME, ENTRE LA LEY Y LA CONSTITUCIÓN: UNA INTRODUCCIÓN HISTÓRICA A LA FUNCIÓN INSTITUCIONAL DE LA CORTE SUPREMA DE JUSTICIA, 1886-1915 [Between the Law and The Constitution. A Historical Introduction to Supreme Court of Justice's Institutional Function, 1886-1915] (Editorial Pontificia Universidad Javeriana, 2007) at 82-94.

15 In the Colombian Constitutional Law, the powers of Executive branch regarding legislation can be divided in two types: (1) further developments of Acts of the Congress, named Regulatory Decrees Decretos Reglamentarios; and (2) Decrees enacted to the Executive Branch based on legislative powers granted by Congress or even by the Constitution, named Law Decrees Decretos leyes.

${ }_{16}$ See Manuel José Cepeda-Espinosa, Judicial Activism in Violent Context: The Origin, Role, and Impact of the Colombian Constitutional Court, 3 WASH. U. GLOBAL StUD. L. Rev. 529 (2004), at 538.

17 The Colombian Constitution provides another well-known mechanism on relief before fundamental rights violations, named acción de tutela, judicial procedure similar to the writ of certioriari of the American constitutionalism. However, this paper will not analyze this mechanism in order to be focused in the abstract judicial review through the PAU. For a general understanding about acción de tutela and other similar judicial actions in the Latin American context, see generally Allan R. Brewer Carías, Constitutional Protection of Human Rights in Latin America (Cambridge University Press, 2009), at 228-32.

18 See Julio Ríos-Figueroa, Institutions for Constitutional Justice in Latin America, in CoURTS IN LATIN AmericA (Gretchen Helmke and Julio Rios Figueroa ed., 2011) at 43-44.

19 See Cepeda-Espinosa, supra note 15, at 541.

${ }^{20}$ See generally Restrepo, Esteban, Reforma Constitucional y Progreso Social: La "Constitudonalización de la Vida Cotidiana" en Colombia" [Constitutional Reform and Social Progress: The "Constitutionalization" of Ordinary Life in Colombia], Sela (Seminário en latinoamérica de Teoria Constitucional y Politica) Papers. Paper 14, 2002, 
The limitations, in terms of access of the citizens to the PAU, suffered a dramatic change after the Colombian Constitution of 1991. This new Constitution was a part of the democratization process in Latin America during the 1990s and has, among its main characteristics: (1) a broad bill of rights that covered not only civil liberties but also a wide-ranging provision about social and cultural rights; (2) the incorporation of main Human Rights treaties as a part of the Constitution like standard for interpretation of meaning of constitutional right, ${ }^{21}$ and (3) a diverse and ample mechanism of political participation. ${ }^{22}$

One of the expressions of this expansion on participation was the change regarding access to the PAU. The 1991 Constitution provides that the PAU itself is a political right. It means that the PAU is a constituent of the citizenship and democratic participation rights protected by the Constitution, beyond a mere judicial procedure. ${ }^{23}$ For this reason, in the Latin American context the PAU is recognized by several scholars as one of the broadest mechanisms of access to justice regarding constitutional adjudication, even characterized as "the most open and accessible constitutional review system in the Western world." 24

\section{The Structure of the Abstract Judicial Review and Its Outcomes}

The procedural matters of the PAU are regulated in the Decree 2067, 1991. ${ }^{25}$ This statute disposes a simple proceeding for this action, according to the broad access explained above, as well as the nature of the PAU like a political right. The structure of the action is the following: In the first stage, the citizen filed a lawsuit before the Constitutional Court. One of the Justices of the Court revises the admissibility requirements of the Decree 2067, 1991, together with the condition of citizenship of the plaintiff. When these requirements are fulfilled, the Court opens the case to public participation. In this stage several amicus curiae are received from different persons and institutions (law schools, think tanks, NGOs, individuals citizens, and foreign institutions among others). The Government also submits its written arguments, generally in order to support the constitutionality of the concerned statute. In very few cases, the Court arranges public hearings. In the third phase, the same Justice that reviewed the admissibility requirements prepares a draft of the decision and the Court in banc debates it. The decision is adopted by a minimum of five affirmative votes of the nine Justices. Similar to the U.S. Supreme Court, concurring and dissenting opinions are allowed as a part of the decision.

\footnotetext{
http://digitalcommons.law.vale.edu/vls sela/14 (last visited, Nov. 24, 2014).

21 CONSTITUCIÓN PolítiCA DE COLOMBiA [C.P.] art. 93.

22 See Donald T. Fox \& Anne Stetson, The 1991 Constitutional Reform: Prospects for Democracy and the Rule of Law in Colombia, 24 Case W. Res. J. Int'l L. 139 (1992)

${ }^{23}$ According to Colombian Constitution, Art 40 (6), any citizen has the right to participate in the establishment, exercise, and control of political power. To make this decree effective the citizen may, among other activities, filing public actions in defense of the Constitution and the law. CONSTITUCIÓN PoLITICA DE COLOMBIA [C.P.] art. 40 (6)

24 Manuel José Cepeda-Espinosa, La Defensa Judicial de la Constitución [The Judicial Defense of the Constitution] in FoRTAlezAS DE Colombia (Fernando Cepeda, ed., 2004), at 170. See also also Juan Carlos Rodríguez-Raga, Strategic Deference in the Colombian Constitutional Court, 1992-2006, in CoURTS In LATIN AMERICA (Gretchen Helmke and Julio Rios Figueroa ed., 2011).

25 D. 2067/91, septiembre 4, 1991. DIARIO OFICIAL [D.0.] 40.012 (Colom.)
} 
Two aspects of the procedure should be highlighted. First, regarding the requirements of the lawsuit, the Decree 2067, 1991 article 2 determines the following conditions: (1) transcription of the accused statute or an issue of its official publication, (2) identification of the constitutional norms that the plaintiff considers violated by the statute; (3) arguments that support the claim of unconstitutionality, (4) if the claim is related to a violation of congressional procedure, description of that procedure is necessary, and (5) the legal ground of the jurisdiction of the Court. ${ }^{26}$ Notice that the PAU does not require legal counseling by an attorney or any other requirement of standing beyond the condition of Colombian citizenship and the explanation about the constitutional supports of the claim. Moreover, the statute does not demand a specific argumentative standard regarding the legal ground on the claim, outside a comparison between the statute and the constitutional rules, which includes treaties on human rights ratified by Colombia.

Second, the outcomes of the decisions of the Court are not limited to declaring invalid a statute, in whole or in part. The Court often concludes that the statute is constitutional under a compulsory interpretation of the rule. In other words, the Court "fixes" the meaning of the statute in order to make it compatible with the Constitution. This type of rulings, named decisions of conditional constitutionality, sentencias de constitucionalidad condicionada, are very important as they are used in several cases by the Court in order to protect fundamental rights within the abstract judicial review. Therefore, the Court makes decisions beyond the Kelsenian ideal ${ }^{27}$ of the constitutional tribunal as "negative legislator", and promotes protection of constitutional rights through a particular and binding interpretation of statutes. In fact, these binding interpretations are expressions of the power of the Court in the process of law making as "positive legislator". ${ }^{28}$

Likewise, these binding interpretations by the Court have a specific effect regarding protection of the rights of minorities and disadvantaged populations. In the Colombian case, the PAU is often used to improve fundamental rights of minorities, through claims of "expansion" of the scope of guarantees enacted by Congress in a narrow way and under a discriminatory basis. ${ }^{29}$ In other cases, the conditional interpretation has been used in order to resolve lack of protection on fundamental rights regulated by acts of Congress. ${ }^{30}$ For this reason, some scholars conclude that the PAU has a specific role in the social change and even an emancipatory function about

$26 / d$. article 2. The author has done the translation.

${ }^{27}$ It refers to the paradigm of adjudication by constitutional courts drafted by Hans Kelsen. See HANS KELSEN, GENERAL THEORY OF LAW AND STATE (The Lawbook Exchange Ltd. 2009) (1945) at 157-62

${ }^{28}$ About the distinction between the roles as positive and negative legislator of the constitutional courts See Alec Stone Sweet, Why Europe Rejected American Judicial Review: And Why It May Not Matter, 101 MicH. L. Rev. 2744 (20022003) at 27766-69.

${ }^{29}$ For example, in different decisions the Colombian Court has extended several economic guarantees of married couples to unmarried ones, even same-sex couples.

${ }^{30}$ An example about this trait of decisions is the protection of compulsory and free elementary education, provided by Article 13 (3) (a) of Additional Protocol to the American Convention on Human Rights in the Area of Economic, Social and Cultural Rights. The Court concluded that the national statute on primary education in public facilities implied that the Government may impose some costs to the students and their families and, therefore, provided a lower standard of protection of the right to education than Human Rights International Law enacts. Hence, the Court held that this statute must be understood in a way that does not impose any cost or related burden. See Corte Constitucional [C.C.] [Constitutional Court], mayo 19, 2010, Sentencia C-376/10. 
improving fundamental rights of these groups. ${ }^{31}$ Finally, it is important to notice that the effects of the rulings are erga omnes and, therefore, binding for Congress and any citizen or public authority. If the Court declares the invalidity of a legal rule, this statute cannot be further applied because it has been formally expelled from the legal system. Furthermore, when the Court holds a conditional constitutionality decision, the interpretation expressed in the decision will have the same binding effect.

However, more conservative authors consider these decisions, particularly the holdings of conditional constitutionality, violate the democratic principle and the limitations of the judicial activity. Consistent with this approach, judicial activism regarding improvement of rights of minorities, particularly social rights, is inconvenient because it (1) transfers claims that should be assumed by the political process to the judiciary, ${ }^{32}$ (2) adopts policy decisions without political representation, democratic debate, and sufficient data about costs of the measures that must be implemented in order to enforce the judicial decision, ${ }^{33}$ and (3) incites an uneven distribution of resources in the society, because the plaintiffs, through the judicial decisions, obtain more benefits than other groups even more disadvantaged who do not have access to the PAU.

Therefore, the PAU suggests a tension between the democratic principle and the improvement of constitutional rights, particularly regarding minorities and disadvantaged people. Thus, it is important to explain the two sides of this debate: (1) the role of abstract review in social change, and (2) the protection of democratic process and judicial selfrestrain, among others objectives, through limiting access to the PAU.

\section{ABSTRACT JUDICIAL REVIEW AND SOCIAL CHANGE IN DISADVANTAGED POPULATIONS}

Most of developing countries share three characteristics regarding their judicial systems: broad declarations of rights in their Constitutions, tuned with the scope of International Human Rights Law; lack of political representation to minorities; and scarce

\footnotetext{
${ }^{31}$ See Rodrigo Uprimny \& Mauricio Garci'a-Villegas, The Constitutional Court and Social Emancipation in Colombia in DeMOCRATIZING THE DEMOCRACY. BEYOND THE LIBERAL DemOCRATIC CANon (Boaventura de Souza ed., 2005) at 66-100 (explaining how the Colombian Constitutional Court's decisions have promoted social emancipation in cases such housing-credits debtors, indigenous peoples, and LGTB populations).

32 This debate, usually named the counter-majoritarian difficult of the judicial review, has been deeply documented in the American constitutionalism. For a comprehensive overview see Robert M. Cover The Origins of Judicial Activism in the Protection of Minorities, 91 YALE L.J. 1287-1316 (1982).

${ }^{33}$ Several economists have criticized the decisions of the Colombian Constitutional Court because this lack of information and macro economical effects of this decisions. A well-known case in the Colombian Judiciary is the declaration of unconstitutionality of several norms about housing finance regulation, named sistema UPAC, since this system was not "adequate" in terms of the constitutional right to a house in dignity conditions, ruled by Article 51 of the Colombian Constitution. About this debate and the criticism from economics see SERGIO CLAVIJO, FALLAS Y FALLOS DE LA CORTE Constitucional [Failures and Decisions of the Constitutional Court] (Alfaomega - Cambio 2001). For an answer to criticism regarding "economic decisions" of Colombian Court see Rodrigo Uprimny \& César Rodríguez, Constitución y modelo económico en Colombia: hacia una discusión productiva entre economia y derecho, [Constitution and Economic Model: Towards a Productive Debate between Economics and Law] in DEBATES DE CONYUNTURA ECONÓMICA No. 61 (Fedesarrollo, 2001).
} 
resources to enforce of these ample rights. Hence, the protection of fundamental rights often is not allocated in the political process, but enforced through judicial actions. The abstract judicial review is, therefore, the new venue to guarantee the constitutional rights that the minorities cannot conquer through the political process at Congress. In other words, "litigation was becoming the arena where the policies of the state were to be measured against the promises of the Constitution." 34

Judicial review has an important impact in the protection of rights and social change and, accordingly, access to courts is a critical issue regarding this protection. One of the strategies used by minorities in order to obtain safeguarding of their rights through judicial decisions is Public Interest Litigation - PIL. This action is based on identifying a minority or disadvantaged population with a specific issue of violation of constitutional rights. Leaders within the community, clinics from law schools, or NGOs "translate" these needs in terms of legal claims and file lawsuits before courts to obtain protection of concerned constitutional rights. This protection will cover not only the plaintiffs, but also the population to share the same situation. It is the most important difference between the PIL and "common litigation". While common litigation is focused on dispute resolution in favor of the parties involved in the legal procedure, the PIL seeks to obtain changes in State policies than can impact disadvantaged or discriminated populations. The PIL is, therefore, focused on structural change in the society derived to broad judicial decisions that alleviate discrimination through specific orders to the State towards constitutional rights guaranteeing. ${ }^{35}$

Consequently, the PIL is closely related to access to justice to the poor, legal empowerment, and in a broader sense, the protection of minorities that are excluded to the political process as mean of protection of rights. Accordingly, the PAU is a type of Public Interest Litigation that operates as a way to improve the rights of disadvantaged populations. As some authors express, the link between the PAU and social change in Colombia may be explained in the openness of this action and its minimal requirements of standing. Thus, the PAU "works not only as a democratic and participative way of exerting control on political power, but also as an effective tool to protect fundamental rights by allowing the possibility of challenging laws that violate such rights. "36

\footnotetext{
${ }^{34}$ Menaka Guruswamy and Bipin Aspatwar, Access to Justice in India. The Jurisprudence (and Self Perception) of the Supreme Court, in Constitutionalism of the Global South. The Activist TRIBUnals of InDIA, SOUth AfRICA AND CoLomBIA (Daniel Bonilla Maldonado ed, 2013), at 347.

35 For a definition of Public Interest Litigation since different approach see James Goldston. Public Interest Litigation in Central and Eastern Europe: Roots, Prospects, and Challenges. 28 Hum. Rts. Q. $492-527$ (2006) at 496. "PIL is one phrase for a phenomenon that has been described with many different terms: human rights litigation, strategic litigation, test case litigation, impact litigation, social action litigation, and social change litigation are among the most common. Some see the defining feature of PIL as "seeking to precipitate social change through court-ordered decrees that reform legal rules, enforce existing laws, and articulate public norms." Others note that PIL is "litigation designed to reach beyond the individual case and the immediate client"; that it involves "court-driven approaches in producing significant social reform"; and that it amounts to "espousing causes through litigation." Still others suggest that PIL seeks "to help produce systemic policy change in society on behalf of individuals who are members of groups that are underrepresented or disadvantaged." In the US context, where much PIL originated, the phrase public law litigation has been used to refer to cases involving "allegations broadly implicating the operations of large public institutions such as school systems, prisons, mental health facilities, police departments and public housing authorities; and remedies requiring long-term restructuring and monitoring of these institutions." [Footnotes omitted]

${ }_{36}$ Manuel Iturralde, Access to Constitutional Justice in Colombia. Opportunities and Challenges for Social and Political Change, in Constitutionalism of the Global South. The Activist Tribunals of India, SOUth Africa And Colombia
} 
The barriers imposed by the political system to minorities and disadvantaged populations also facilitate the judicial activism in the developing countries courts. In a context of inefficiency of political process as an adequate venue of relief to constitutional grievances, most complaints regarding fundamental rights protection are processed by the judicial system. Its decisions, also, are not delimitated within the traditional boundaries of judicial adjudication, but include rulings that impose a particular policy before the State that determines the scope of guarantee of the concerned fundamental right. ${ }^{37}$ For instance, recently the Colombian Congress passed a law about a wide-range regulation to the right to health. The Constitutional Court must review these systematic regulations of fundamental rights (statutory laws, leyes estatutarias) before they come into force. The Court decided ${ }^{38}$ that some articles of the regulation, particularly related to the range of treatments and medications covered by the health system, should be interpreted in a flexible manner, in order to protect the right of life and personal integrity of the patients. Although the compulsory reviewing of statutory laws is not, strictly speaking, a form of PIL, during the judicial procedure the Court received several amicus curiae from different NGOs and health system users' associations. These documents helped the Court to shape the conditions imposed to the Government through a decision of conditional constitutionality. Of course, binding interpretations about the statutory law modify the scope of the health system passed by Congress. ${ }^{39}$

\section{Examples of the Impact of Abstract Constitutional Review in Disadvantaged Populations and Minorities}

The PAU has impacted different populations in Colombia regarding improvement of fundamental rights. Two of the most paradigmatic examples of this influence are the protection of the rights of LGTB populations and the decisions of the Colombian Constitutional Court about the forced displacement in Colombia.

The construction of the LGBT rights in Colombia has been entirely developed by decisions adopted within the PAU. Because of electoral reasons and a conservative social basis in Colombia, Congress has been unable to pass legislation about the legal framework of LGBT populations. This situation has helped to maintain a systematic discrimination against the LGBT community and particularly same-sex couples, which pursue an identical legal status that their different-sex counterparts. Accordingly, the protection of the rights of this minority has been based on several decisions on the Colombian Court, mostly through using conditional constitutionality.

The pattern of decision on this kind of case is similar. Colombian legislation about civil law, social security, labor law, etc., has been enacted taking into account only a traditional understanding about family, relied on different-sex couples. The strategy of minorities has been filed before the Court several lawsuits based on the discriminatory

\footnotetext{
(Daniel Bonilla Maldonado ed, 2013) at 365.

37 Nevertheless, the understanding of constitutional and supreme courts as policy-makers is not exclusive of developing countries. For an overview about the topic in the case of the U.S. Supreme Court see Robert Dahl, Decision Making in a Democracy: The Supreme Court as a National Policy-Maker, 6 J. PUB. L. 279 (1957).

38 Corte Constitucional [C.C.] [Constitutional Court], mayo 29, 2014, Sentencia C-313/14

39 Indeed, the Minister of Health expressed several concerns about how the Court had modified, through judicial review, some rules of the statute regarding medications and medical procedures covered by the Colombian health system.
} 
effect of this type of regulations, claiming to a decision of conditional constitutionality that may include same-sex couples as recipients of the effects of the statutory law.

Two cases illustrate the uses of the PAU as a public litigation strategy. In the first one, ${ }^{40}$ a group of NGOs identified dozens of rules in different matters, from rules on domestic violence to immigration laws, all of them based on different-sex couples as a criterion to provide legal effects among the partners. Then, the plaintiffs accused those rules before the Court based on the same argument in all the cases: the legislative rules imposed a discriminatory treatment against same- sex couples although they were in the same situation that different-sex couples, because both build a "singular community of life" and intend to bring support each other. The Court acknowledged that there was no justification to provide a different treatment and, for this reason, concluded that this differentiation violated the prohibition of discrimination based on sex, recognized by the Colombian Constitution and several human rights treaties. Accordingly, the Court used again the formula of conditional constitutionality, in order to hold a binding interpretation of the accused rules that incorporates the same-sex couples as beneficiaries of the legal consequences contained in such laws.

The conditionality of rules about marriage is a second example. ${ }^{41}$ The Colombian Civil Code regulates marriage only with regard to a relationship between a woman and a man. ${ }^{42}$ A group of citizens filed a claim of PAU against this rule with a similar argument: the legislation was discriminatory because it failed in providing a legal and contractual recognition in favor of same-sex couples who comply the same requirements to marriage except to gender difference. The Court accepted this claim and therefore (1) declared that the Civil Code rules have a "deficit of protection" against same-sex couples, (2) ordered Congress to pass legislation on recognizing a legal and contractual status to same sex couples on identical basis than marriage regulated by the Civil Code, and (3) provided that if two years after the decision Congress had not passed this legislation, same-sex couples would obtain legal recognition of their relationship, using the marriage rules.

Another example of nexus between the PAU and protection of minorities and disadvantaged populations is the case of internal forced displacement. As a consequence of the Colombian armed conflict millions of people, particularly residents of rural areas, have been victims of internal forced displacement. ${ }^{43}$ This situation means a continuous and systematic violation of fundamental rights, because the constitutional complaints are not concentrated only in access to land, but also in different rights interfered by forced

\footnotetext{
40 Corte Constitucional [C.C.] [Constitutional Court], enero 28, 2009, Sentencia C-029/09.

41 Corte Constitucional [C.C.] [Constitutional Court], julio 26, 2011, Sentencia C-577/11

42 Código CIVIL (Civil Code) Article 113.

${ }^{43}$ As the Office of United Nations High Commissioner for Refugees explains, the situation of forced displacement in Colombia is particularly serious. According to official data provided by the Colombian Government, in March 2013, over 4.7 million people were victims of internal forced displacement. The Office of UNHCR also stresses that "Despite the Government's efforts to improve its response to forced displacement and implement the victims Law, widespread insecurity and violence including the forced recruitment of children and youth, sexual and gender-based violence (SGBV), threats, disappearances and murders continue to occur in many regions. The growth of displacement in urban areas and continued conflict in remote rural areas that are difficult to access for UNHCR and its partners, highlight the need for the continuation of prevention and protection programmes at national and local levels." UNHCR, 2014 UNHCR COUNTRY OPERATIONS PROFILE - COlOMBIA, http://www.unhcr.org/pages/49e492ad6.html (last visited Nov. 15, 2014).
} 
displacement, like education, health services, personal safety, and guarantee of minimum standards of living on food, housing, public utilities, and so forth. ${ }^{44}$

Most complaints from displaced populations have been assumed by Courts through acciones de tutela, ${ }^{45}$ especially the well-known "structural" decision T-025, 2001, which the Colombian Constitutional Court held comprehensive orders to different bodies of Colombian government regarding the different faces of violations of displaced populations' fundamental rights. ${ }^{46}$ However, the PAU have had a role in the protection of these communities, particularly through decisions of conditional constitutionality that bonds the validity of statutory rules to taking into consideration the protection of displaced people's rights. For instance, in the decision C-278, 2007 the Court examined a statute that ensured humanitarian assistance to displaced families, mainly through a monetary subsidy. Nevertheless, the law limited that assistance for a maximum of six months. The Court held that such limit violates the fundamental rights of displaced populations, because beyond this period it was very possible that vulnerability of displaced families still continues. For this reason, the Court struck down the rule about the limit of six months and ordered, through a conditional constitutionality decision, that the humanitarian assistance should be extended until the displaced person would be able to guarantee her self-sustaining. ${ }^{47}$

\section{Forms of Improvement of Access to Justice in the Public Interest Litigation}

The PIL has a recognized nexus to social change and improvement of rights in developing countries, therefore a critical area about this issue is the access to this type of action. This is because any change that imposes restrictions to the access to constitutional actions would affect fundamental rights protected through the PIL. Hence, regarding this issue it is possible to find two ways to guarantee access to justice: simplification of procedure based on (1) statutory reform, or (2) precedent reform.

The first scenario is the PAU. As I explained above, after the enactment of 1991 Constitution, the PAU became a part of the fundamental rights of the citizens. Therefore, the implementation of this public action had based on a simple procedure with minimal requirements of standing and without any request of legal counseling, court fees or timing. ${ }^{48}$ The main idea of this approach was that the PAU should be a "tool of participation" 49 of the citizens in the protection and improvement, not only about the constitutional rights, but also to the Constitution as a whole. ${ }^{50}$ Besides, this new

\footnotetext{
44 See César Rodn'guez-Garavito, Beyond the Courtroom: The Impact of Judicial Activism on Socioeconomic Rights in Latin America. 89 Tex. L. Rev. 1669 (2010-2011) (explaining how the Colombian Constitutional Court has assume the protection of rights of displaced populations through a structural-violation basis)

45 Supra note 16

46 See Iturralde, supra note 35 , at 385.

47 Corte Constitucional [C.C.] [Constitutional Court], abril 18, 2007, Sentencia C-278/07.

48 Even though, the public action based solely on alleged unconstitutionality of congressional procedure must be filed within a year after the presentment of the law. The same rule applies regarding the PAU against constitutional amendments. See CONSTITUCIÓn PolitiCA DE COLOMBIA [C.P.] art. 242(3).

49 For this reason, it is a common understanding in the Colombian constitutionalism that the PAU is one of the mechanisms of democratic participation, like the right to vote or the right to control the political power. See Eduardo Cifuentes Munoz, Jurisdiction constitucional en Colombia [Constitutional Jurisdiction in Colombia], in lus ET PRAXIS (Vol. 8, 2002), at 283-317.

50 Accordingly, the Colombian Constitution, article 241, confers to the Constitutional Court its main duty: to protect the
} 
approach was a reaction to the limited use of the action of unconstitutionality during the 1886 Constitution, when the action of unconstitutionality was used only for the purposes of isolated elites and, for the same reason, without any connection with protection of fundamental rights of minorities or disadvantaged populations. ${ }^{51}$

Hence, if the PAU is one of the mechanisms of enforcement of the participative democracy, the access to this judicial procedure must be ample to all the citizens. Consequently, the legislation that regulates this action ensures this broad access through a simplification of procedures.

The second scenario refers to the simplification of procedures in a precedent-based basis. This is the case of the Indian Supreme Court, when several judicial decisions have built public interest litigation rooted on "a mixture of the substantive and the procedural, animated by the spirit of the [Indian] Constitution." 52 The Indian Supreme Court has used the substantive due process clause of the Indian Constitution, as well as the broad scope of the article 21 about the right to live with human dignity as a part of the liberty clause, to design a judicial procedure that can assume systematic violations on fundamental rights of disadvantaged populations as prisoners, famished families, and communities affected by environmental factors, among others issues. The Court provided a PIL informal procedure based on the following key features, explained by Ghai \& Cottrell. (1) The ability of organizations or groups to bring cases on behalf of others who are unable because of disadvantage to do so; (2) informal means of beginning cases, even by letter or postcards, or because of the direct action by the Court on the basis of newspapers reports; (3) proactive ways of finding evidence that include appointing of committees to produce reports to the Court; (4) requiring of reports to governmental agencies about its compliance on the Court's orders; and (5) wide range of remedies to grievances, beyond the traditional rulings given by courts. ${ }^{53}$

The Indian Court, consequently, has configured an "epistolary jurisdiction" which can be activated by a simple postcard. ${ }^{54}$ It is difficult to imagine a broader access to justice and a more minimum level of standing. However, the Indian Court not only opened this ample system of access to justice, but also modified its own structure to include a PIL cell within the Court. ${ }^{55}$ This department processes the letter petitions and decides about its admissibility, according to the Guidelines on Public Interest litigation enacted by the Court. ${ }^{56}$ Currently, this admissibility is concentrated only on a specific group of cases about bonded labor, neglected children, violation of labor laws, issues about jails complaining of harassment and due process of prisoners, violence against women, complaints submitted by persons who belong to Scheduled Caste or Tribes, petitions on protection of cultural heritage and environment, and claims from riot victims. ${ }^{57}$

In sum, instruments to protection of fundamental rights in developing countries tend to offer ample and simple judicial procedures in order to guarantee the broadest access possible to the Courts, particularly in favor of disadvantage populations or

\footnotetext{
integrity and supremacy of the Constitution.

51 See Gonzalez Jacome, supra note 13.

52 Ghai \& Cottrell, supra note 5 , at 16

53 Id. at 17.

54 The concept of epistolary jurisdiction is explained by Guruswamy \& Aspatwar, supra note 33 at 348-52.

55 Id. At 352-53

56 Supreme Court of India. COMPILATION OF Guidelines to Be Followed for Entertaining LetTers/Petitions RECEIVED IN THIS COURT AS PUBLIC INTEREST LITIGATION. http://supremecourtofindia.nic.in/circular/guidelines/pilguidelines.pdf (last visited Nov. 16, 2014).

57 See Guruswamy \& Aspatwar, supra note 33 at 353.
} 
minorities, as groups under special constitutional protection because of their socioeconomic or political vulnerability. The origin of this simplification of procedures can be founded in the legislative rules (statutory-based simplification in the Colombian case), or in decisions of the courts that uphold flexible procedures to access to justice (precedent-based simplification in the Indian case).

Nevertheless, the undeniable advantages of simplification on procedures can be threatened for narrow understandings about access to justice by courts. Hence, the same precedent-based mechanisms that helped to open the access justice in the Indian case may limit the ways to enter to the system of justice, particularly to disadvantaged populations and minorities in the Colombian case. Besides, a restrictive view on simplification of procedures could be justified in protecting the democratic principle and the definition of rights within the political process. Also, respecting separation of powers would force the judiciary to assume a self- restrained position in their decisions. ${ }^{58}$ The following arguments will undertake this matter.

\section{THE TRANSFORMATION OF THE ADMISSIBILITY REQUIREMENTS}

Although the acción de tutela has been the most popular constitutional relief for protection of fundamental rights in Colombia, the PAU has gained an important role in the same area during recent times. For instance, while in 1992 the Court held 52 decisions on PAU, in 2013 the numbers raised to 196. Besides, 2001 shows an impressive peak of 368 decisions. ${ }^{59}$ The Court is often deferent to the legislative branch, as shows statistical data during the period 1992-2004. In this range, 62\% of the PAU decisions affirmed the constitutionality of statutes and in $24 \%$ of cases the Court decided to strike down the legislation. In $6 \%$ of the cases the Court held a decision of conditional constitutionality and the Court held "inhibitory" decisions ${ }^{60}$ in $8 \%$ of the cases. ${ }^{61}$

This last data is very important for the purposes of this paper. In $8 \%$ of the cases, the Full Chamber (Sala Plena) decides that the PAU did not comply with formal requirements and, for this reason, an inhibitory decision must be adopted. However, a single Justice adopts most inhibitory decisions in the admissibility stage. Unfortunately, the Court does not keep statistical data about the inhibitions adopted in this stage, but it is possible to conjecture that the decisions of inhibition in the admissibility stage could be a half of each Justice workload. ${ }^{62}$

\footnotetext{
58 Judicial restraint and the counter-majoritarian difficult are two of the most important issues regarding constitutional adjudication. One of the most cited scholars about this matter is Alexander Bickel who, in fact, proposed such doctrine of the counter-majoritarian power of courts before political process. See Alexander Bickel, THE LEAST DANGEROUS Branch. The Supreme Court And the BAR OF Politics. (Vail-Ballou Press Inc., 1986) 1962. For an application of this legal theory in the Colombian constitutionalism see Gloria Lopera-Mesa, La problemática iegitimidad de la justicia constitucional [The Problematic Legitimacy of Constitutional Justice], in ANUARIO IBEROAMERICANO DE JUSTICIA CONSTITUCIONAL (2001), at 227-56.

59 Estadísticas, Relatoría dE LA CORTE CONSTItucional dE Colombia. http://www.corteconstitucional.gov.co/relatoria/estadisticas1992-2014.png (last visited Nov. 20, 2014).

60 The Court holds an inhibitory decision when refuses to judge about substantial matter, because the lawsuit does not comply with admissibility formal requirements.

61 See Iturralde, supra note 35 , at 384.

62 The support of this statement relies on empirical evidence. The author served by thirteen years in the Colombian Constitutional Court and he was in charge of the admissibility process where an average of a half of the PAU's claims
} 
Inhibitory decisions are mostly related to breaching of precedent-based requirements imposed by the Constitutional Court to admission of lawsuits on the PAU. Through the decision C-1052, $2001^{63}$ the Court concluded that even though the Rules of Procedure of the PAU do not provide specific requirements about standing, it was necessary to "qualify" the public action, in order to prevent tenuous lawsuits or claims based on only policy matters, different to constitutional legal grounds. Therefore, the Court interpreted the statutory requirement of expressing arguments that support the claim of unconstitutionality, and concluded that this condition refers to accomplishment of substantive requests of clarity, certainty, specificity, pertinence, and sufficiency in the argumentation. ${ }^{64}$

The condition of clarity refers to argumentative coherence of the claim. Accordingly, the Court requests that the arguments of the claim be comprehensible. The condition of certainty means that the lawsuit must identify a legal rule "truly embedded" 65 in the statute. The condition of specificity requests that the grounds of the claim be identifiable, different from vague and undefined assumptions of the plaintiff. The condition of pertinence requires that the arguments of the claim be rooted in an abstract constitutional ground. It means that the legal argument should offer an objective comparison between the statute and the Constitution, outside of any another consideration related to neither a specific case nor a "personal and subjective understanding of the statute". Finally, the condition of sufficiency demands that the plaintiff offers a comprehensive, complete, and persuasive argumentation.

Since these requirements are extremely vague and ample, they have allowed the Court to have flexible and broad power to refuse PAU lawsuits. In general terms, the Court has used these precedent-based requirements as mechanism of narrowing of access to the PAU, through overusing of inhibitory decisions. ${ }^{66} \mathrm{~A}$ reasonable explanation of the precedent-based limitations is the traditional struggle in the Latin American judiciary between new constitutionalism and legal formalism. ${ }^{67}$ The Constitution of 1991 made more flexible access to justice and, therefore, simplified, among other strategies regarding protection of rights, the use of the PAU as mechanism of public interest litigation. The PIL, as I explained before, changes the traditional approach about the separation of powers and the formal distinction between judges and policymakers. This movement, where the constitutional courts enhance fundamental rights through concrete actions and orders to the Government, is named the new constitutionalism. ${ }^{68} \mathrm{~A}$ reaction from this approach is the legal formalism, based on focusing adjudication only in legal matters outside any consideration about the relationship between judicial

were dismissed because of the lack of compliance with the precedent-based requirements. However, the Court does not include these preliminary decisions in its reports and, therefore, building statistical data about the matter is almost impossible.

${ }^{63}$ Corte Constitucional [C.C.] [Constitutional Court], octubre 4, 2001, Sentencia C-1052/01.

$64 \mathrm{ld}$.

$65 / d$.

${ }^{66}$ Although the Court does not provide specific statistics about the rate of inadmissibility because of the breach of precedent-bases requirements, it is possible to infer that at least a half of the lawsuits are refused by this reason.

67 See lturralde, supra note 35 , at 369 .

68 For a comprehensive analysis about the new constitutionalism, not only in developing countries, but also in constitutional courts of developed countries, see RAN HIRSCHL. TOWARDS JURISTOCRACY: THE ORIGINS AND CONSEQUeNCES OF THE NEW Constitutionalism (Harvard University Press, 2007). 
decisions and policy. ${ }^{69}$ Thus, the underpinning of the requirements to access to the PAU would be a defense of thisformal understanding about judicial adjudication, as well as a way to judicial self-restraint.

For instance, the requirement of pertinence relies on that distinction. The arguments of the PAU must address only "constitutional matters", different to policy reasons. Hence, the Court makes a distinction, actually an artificial and arbitrary one, between constitutional arguments, which are valid within judicial adjudication, and policy reasons that supposedly must be outside of the judicial reasoning.

\section{Justifications and Problems on the Precedent-Based Requirements}

The struggle between new constitutionalism and legal formalism shows that narrowing the access to the PAU is not a haphazard decision of the Colombian Court. It is possible to find two main reasons which support that limited access. The first one is the democratic principle and the protection of separation of powers. Most of criticisms against the PAU and particularly the decisions of conditional constitutionality are based on consider that this kind of rulings have a legislative approach beyond formal judicial adjudication. Then, the judges become policymakers and Congress loses its importance as democratic venue to the definition of the fundamental rights' scope. For this reason, it is necessary that courts adopt a self-restraint mechanism in order to prevent that judicial decisions become in a mere policy and monitoring of the actions of the Government. ${ }^{70}$

The second one is related to the efficiency in the work of the Court. Poorly supported lawsuits affect responsiveness capability of the Court and make an inefficient use of scarce judicial resources. As it was explained above, the PAU activates the participation of several government authorities and civil society stakeholders. Then, an unfounded claim wastes these efforts because the Court will not be able to hold a substantive ruling different to an inhibitory decision. In order to support this argument, the Court has used the abuse of the rights doctrine, ${ }^{71}$ traditional in civil law jurisdictions. ${ }^{72}$ This doctrine states that law does not protect an abusive exercising of

\footnotetext{
69 The struggle between legal formalism and new constitutionalism also offers two different discourses about how constitutional judges understand fundamental rights, principles and legal texts. As David Landau states "there are presently at least two completely different judicial worldviews about constitutional law in Latin America: (1) a traditionalist Latin American view that minimizes the role of constitutions by focusing on concrete rules, which form a relatively small part of constitutional discourse; and (2) a newer view that focuses on the principles and values behind constitutions, and thus tends to read them broadly. These worldviews are extremely rich, integrating ideas about what law is, interpretative methods, theories of the judicial role in a political system, and substantive values into a fairly coherent whole. Further, each of these worldviews can be identified with a particular type of social actor as its likely carrier: As I will suggest, the traditional worldview is most closely associated with career judges, whereas the alternative view is most likely to be espoused by public or constitutional law scholars. This matching of actors and worldviews, although somewhat crude, helps us to discipline, clarify, and structure the legalist model considerably." David Landau, The Two Discourses in Colombian Constitutional Jurisprudence: A New Approach to Modeling Judicial Behavior in Latin America, 37 GeO. WASH. INT'L L. REV. 687 (2005), at 689.

70 This kind of criticisms had been expressed in the case of the Indian Supreme Court regarding its approach about public interest litigation. See Guruswamy \& Aspatwar, supra note 33 at 347-48. The necessity of protection of separation of powers within the PAU had been also required in the case of the Colombian Court, See Clavijo, supra note 32.

71 Corte Constitucional [C.C.] [Constitutional Court], diciembre 2, 2003, Sentencia C-1148/03.

${ }^{72}$ For a classic and comprehensive explanation about the doctrine of abuse of rights in civil law jurisdictions See Julio
} 
rights. Then, in the case of the PAU looks reasonable that access to justice can be restricted who knowingly files unsubstantiated lawsuits.

Nevertheless, the precedent-based requirements show two principal issues. On one hand, these requirements inflict a barrier on access to judicial system, derived to vagueness of the conditions explained before. The admissibility conditions are very broad and flexible and, for this reason, it is always possible that a lawsuit can be accused of failing one or more of the conditions, even under a subjective and random judicial scrutiny. The abstract nature of the PAU reinforces this risk. Also, the PAU lawsuits have an obvious lack of contextual information, because (1) they cannot be supported in a particular case, and (2) the precedent-based condition of pertinence requests such abstract nature of the claim. However, the absence of factual and contextual information in the lawsuit plays against the accomplishment of the precedent-based requirements, because it diminishes the argumentative strength of the claim. Besides, the mere written legislation omits this contextual information and such data is necessary to adopt a decision regarding rights involved in a judicial controversy. It is a circular reasoning that narrows the access to the PAU even though the simplification of procedures endorsed by the Colombian Constitution and concerned statutes. ${ }^{73}$

On the other hand, the ample and vague requirements of admissibility bestow the Court an almost unlimited judicial discretion over which cases are admitted and which are not. Therefore, the Court has a powerful mechanism of docket control with virtually any control by the plaintiff. Although the plaintiff would ask for a revision of the inadmissibility, the rate of decisions reversed by the Full Chamber of the Court is very low. Thus, the Court has built a strategy of "informal docket control" through the precedent-based requirements. ${ }^{74}$ This strategy not only works in order to prevent the admission of tenuous claims, but also to avoid controversial cases or further decisions with complex political implications. In sum, the precedent-based requirements enable an informal and unrestrained way of limiting access to the PAU, because these conditions are vague and flexible. Even a very well-constructed lawsuit can eventually fail any of these requirements, only because the claim does not fit in the agenda ${ }^{75}$ of the Court or of the Justice in charge of the admissibility stage.

Cueto-Rúa, Abuse of rights, 35 LA. L. REV. 965 (1974-1975).

73 See Julio Ri'os-Figueroa, Institutions for Constitutional Justice in Latin America, in COURTS IN LATIN AMERICA (Gretchen Helmke and Julio Rios Figueroa ed., 2011) (explaining how the abstract judicial review on constitutional issues is not an adequate mechanism for protection of fundamental rights, because of the lack of contextual information in lawsuits).

74 "Access to justice is linked to docket control, giving courts the prerogative to select the cases they want to hear. Docket control can be found in different forms, identifying technical or substantive grounds as criterion of selection, and, in the latter case, allowing courts to avoid having to deal with particular constitutional issues. ... Docket control permits courts to set their own agenda, to determine their own pace, and to maintain legitimacy in situations in which political forces might not support the specific outcome ordered by the court." Patricia Popelier \& Aida Aracely Patino Alvarez, Deliberative Practices of Constitutional Courts in Consolidated and Non-Consolidated Democracies, in THE Role of Constitutional Courts in Multilevel Governance (Patricia Popelier, Armen Mazmanyam and Werner Vanderbruwaene ed, 2013), at 208-2014. (Explaining the link between wide access to the judicial review in Latin America and models of limited access in European tribunals).

$75 \mathrm{ld}$, at 208. 


\section{Precedent-Based Requirements and Disadvantaged Populations}

The limitations imposed by precedent-based requirements have important consequences in the use of the PAU by minorities and disadvantaged populations. First, because of the absence of specific and statutory-based criteria of admissibility, the requirements are not known widely. Only a few attorneys and law firms, commonly integrated by former officers of the Court, have the specific knowledge about these conditions. Surprisingly, the precedent-based requirements are not a part of syllabi in regular courses on constitutional procedures ${ }^{76}$ and, for this reason, only legal counselors with a previous experience dealing with cases before the Court can anticipate outcomes related to inadmissibility based on these requirements. This situation affects the access to court of minorities and disadvantaged populations, because usually they cannot afford the high attorney fees of such specialized legal counselors and legal firms.

Second, the precedent-based requirements generate the "hyper-centralization" of the PAU in this kind of exclusive attorneys and law firms. Then, minorities and disadvantaged populations may access to the PAU only through an NGO or other institution able to process legal claims about fundamental rights across the complex and vague requirements of admissibility. Consequently, the PAU is currently more used by corporations, political parties, congressmen or even the Government itself, than by discriminated communities or other marginalized actors. Furthermore, these actors use the PAU in a strategic basis, closely related to removing inconvenient legal rules for business or political purposes, but without any relation to protection of fundamental rights. In contrast, many decisions promoted by private actors often are oriented to the preservation of status quo and the limitation of measures about fundamental rights improvement. ${ }^{77}$

Therefore, the precedent-based requirements affect the empowerment of minorities and disadvantaged communities through the PAU, and impede the social change derived to using of judicial review as a mechanism of protection of fundamental rights. In fact, these conditions build a barrier to access to justice, because claims based on protection of fundamental rights will be protected only (1) when they fit in the Court's agenda and priorities, and (2) if minorities can access to NGOs or other wellstructured institutions in order to file the lawsuit. The case of protection of gay rights provides an accurate example. In 2009, a citizen filed a PAU lawsuit against the rules on adoption and marriage because they excluded same-sex couples for constitutional protection and legal recognition. The argument was quite simple: according to the Colombian Constitution ${ }^{78}$ the State should not make undue differentiations based on gender or sexual orientation. Therefore, the constitutional relief in the case was extending the protection given by the statute to same-sex couples. Accordingly, several national and

\footnotetext{
76 In civil law countries, studying of case law rules is marginal and traditionally law professors are focused on statutory interpretation. In the case of the PAU, the statute has no any reference to the requirements provided by the Court and, therefore, law students are not familiarized with these rules after their studies. Only few graduate programs specialized in constitutional procedures offer this kind of training.

77 This is the case of PAUs filed against laws that imposes new taxes. It is common that private actors impacted by tax raises enacted by Congress file PAUs in order to strike down this legislation, most of times under alleged violations of legislative procedures. For an example, see Corte Constitucional [C.C.] [Constitutional Court], febrero 15, 2012, Sentencia C-076/12.

78 Constitucíon Política de Colombia [C.P.] art. 13.
} 
even foreign institutions submitted amicus curiae in order to support the invalidity of the discriminatory treatment.

However, the Court eluded taking a substantial decision about a controversial claim and declared, relied on a complex and almost unintelligible holding, that the lawsuit breached the requirement of certainty. ${ }^{79}$ This case is emblematical because all the participants in the judicial process agreed about the substantial matter of the claim and, for this reason, it was clear that the decision of the Court had only a political background "processed" through an alleged breaching of precedent-based requirements. Nevertheless, further decisions progressively struck down discriminatory legal treatments against same-sex couples and opened the Court's agenda about this matter. ${ }^{80}$ Hence, the Court admitted in 2011 a lawsuit regarding the right to marry of these couples, with identical grounds as the 2009 case, but supported by a broad coalition of NGOs. In this case, the Court ruled a decision ${ }^{81}$ on the merits of the case, which declared unconstitutional the definition of marriage provided by the Colombian Civil Code, because it imposed a discriminatory treatment based on sexual orientation. Hence, the Court ordered to Congress to enact proper legislation about this matter.

Nevertheless, this decision was not enough in order to protect LGTB rights. Several administrative officers, particularly public notaries, refused to recognize samesex couples' marriage. Many of them just offered an "innominate" contract to legalize such unions. Therefore, some couples, mainly supported by human rights NGOs, sued again before the judiciary, through acción de tutela. Recently, in April 2016, the Full Chamber of the Court decided these cases, ruling that same-sex couples and differentsex are entitled of the equal protection under the law. Accordingly, and given that Congress did not enact any legal rule about this topic, the Court ordered to public notaries and judges celebrate a single kind of marriage, currently regulated in the Colombian Civil Code, regarding both types of couples. ${ }^{82}$

\section{CONCLUSION AND RECOMMENDATIONS}

Simplification of procedures is a common approach to deal with limited access to systems of justice. However, this type of mechanism is confined in legal reform and, for this reason, does not take into consideration other variables, like the power of the judiciary to impose new requirements to access through precedent-based rules. The analysis of these limitations on the Colombian Public Action of Unconstitutionality demonstrates that narrowing access to judicial review inflicts undue burdens to minorities and disadvantaged populations who use the PAU in order to protect their fundamental rights. Even though providing argumentative requirements to abstract judicial review is an important mechanism to safeguard the principle of separation of powers, such conditions must be balanced with the defense of fundamental rights of the citizens.

This harmonizing can be reached through three types of measures. The first one is linking precedent-based requirements and statutory legislation. Particularly in civil law developing countries, the case law is not properly known, because accessing to decisions is difficult and even some cases are not published. Accordingly, the

\footnotetext{
79 Corte Constitucional [C.C.] [Constitutional Court], noviembre 10, 2009, Sentencia C-802/09.

80 See Corte Constitutional supra, note 39.

81 Corte Constitucional [C.C.] [Constitutional Court], julio 26, 2011, Sentencia C-577/11.

82 Corte Constitucional [C.C.] [Constitutional Court], abril 28, 2016, Sentencia SU-214/16.
} 
precedent-based requirements are not known by citizens, even by attorneys outside law firms specialized in constitutional procedures. Besides, these requirements limit the scope of fundamental rights and, therefore, they must voted on Congress as democratic venue in order to define the matter of these limits to access to judicial review. Moreover, defined statutory legislation about requirements of admissibility to the PAU may reduce, at least partially, the vagueness and complexity of these conditions and it also would narrow the ample judicial discretion of the Court regarding this topic.

The second measure is fostering legal literacy. Statutory legislation and case law about requirements regarding access to the PAU should be a part, not also of curricula in law schools, but also of training programs for any citizen, particularly minorities and disadvantaged populations. ${ }^{83}$ The society should know how to access the Court and the specific procedural conditions of constitutional adjudication. In the current situation, the Colombian Court enacts, because of this lack of knowledge, decisions of inadmissibility on an ex post facto basis.

The third measure is judicial accountability. Like other systems of justice in Latin America, ${ }^{84}$ Colombia has a serious lack of statistical data about caseload, docket control and decisions. Then, it is necessary to improve management plans in order to achieve specific information about how many cases are admitted and how many do not, as well as patterns about justification of decisions of inhibition and inadmissibility. This type of information would permit that judiciary and civil society be able to identify whether the docket control used by courts are based on objective considerations or mere political factors. By the same token, publicizing of this statistical data may operate as mechanism of self-control by the Court.

At least in Latin American courts, judicial procedures commonly are not simple instruments to protect fundamental rights, but rather ways to deny constitutional guarantees. The purpose of this paper was, accordingly, to show one of these barriers and identify some instruments to open the doors of judiciary to the citizens.

Recebido em: 10 de junho de 2016.

Aprovado em: 23 de junho de 2016.

\footnotetext{
83 For instance, the Colombian Ombudsman (Defensor del Pueblo) is in charge of the promotion of fundamental and human rights along the country. Regarding protection of fundamental rights, her labor has been focused only in training for vulnerable communities about the content of the rights and their enforcement through the accion de tutela, but she has not included legal literacy programs on the PAU and its access requirements. See DeFENSORIA DEL PUEBLO DE COLOMBIA. AtENCION AL CIUDADANO. http://www.defensoria.gov.co/es/public/atencionciudadanoa/1471/Solicitud-demecanismos-de- protecci6n-de-Perechos-Humanos.htm (last visited, Nov. 25, 2014).

84 See Lisa Bhansali \& Christina Biebesheimer, Criminal Justice Reform in Latin America, in Promoting the RULE OF LAW AbRoAd. In SEARCH OF KNOWLEdge (Thomas Carothers ed., 2006), at 310-12.
} 